\title{
Food selection and consumption of the shrimp Crangon crangon in some shallow marine areas in western Sweden
}

\author{
Leif Pihl and Rutger Rosenberg
}

Institute of Marine Research, S-453 00 Lysekil, Sweden

\begin{abstract}
Crangon crangon L. is the dominant mobile epibenthic species in shallow waters of western Sweden. We report on seasonal food selection, diel food intake, and quantify consumption of C. crangon in 4 different areas with different substrate and exposure. The main food item for smallsized C. crangon were meiofauna, mainly ostracods and harpacticoids. Mid-sized and large shrimp preferred macrofauna such as Mya arenaria, Cardium edule, Nereis spp. and Corophium volutator. In some years also mobile epibenthos - such as Carcinus maenas, C. crangon and mysides - were eaten. Main feeding was during darkness with peaks around dawn and dusk. In summer an additional midday peak was found. Evacuation rate had a negative linear relationship with time; on average the food left the stomach within $2 \mathrm{~h}$. Mean diel food intake in June and September was estimated to be $12.1 \%$ of body wet weight. Total consumption during the ice-free period (April-December) was estimated to range between 3.7 and $14.8 \mathrm{~g}$ ash-free dry weight $\mathrm{m}^{-2}$ in the 4 areas, giving a mean food conversion (P/C) of about $19 \%$. In one area, C. crangon annually consumed 10 to $121 \%$ of the production of Nereis spp., 25 to $97 \%$ of that of C. volutator, and 2 to $68 \%$ of the combined production of the bivalves $M$. arenaria and $C$. edule. It can thus be concluded that $C$. crangon is one of the major benthos carnivores in these shallow areas and exerts a major impact on the infaunal community.
\end{abstract}

\section{INTRODUCTION}

In coastal shallow $(<1 \mathrm{~m})$ waters of Kattegat and Skagerrak the benthic fauna is extremely rich during the warm summer period (Muus, 1967); despite the short season, production is high (Möller and Rosenberg, 1982, 1983; Pihl and Rosenberg, 1982). Among the mobile epifauna, Crangon crangon had the highest mean abundance and highest annual production, about 2 to $3 \mathrm{~g}$ ash-free dry weight (AFDW) $\mathrm{m}^{-2}$ in some areas (Pihl and Rosenberg, 1982); this indicates strongly that this shrimp exerts great impact upon structure and function of benthic communities. C. crangon has also been shown to be the most important carnivore in the Wadden Sea tidal zone (Kuipers and Dapper, 1981); Reise (1978) proposed that predation was the dominant structuring factor for infaunal assembledges in this lower intertidal zone.

This study documents seasonal food selection, diel food intake and quantifies consumption of Crangon crangon in areas differing in substrate and exposure. Results are based partly on field experiments; more than 9000 C. crangon stomachs have been examined.
In connection with this study, production has also been assessed for mobile epifauna (Pihl and Rosenberg, 1982) and benthic infauna (Möller and Rosenberg, 1982, 1983); the consumption by $C$. crangon will be compared with these results.

\section{AREAS INVESTIGATED}

Investigations were carried out in 4 shallow-water areas (Fig. 1): Gullmarsvik in 1977-79, Sandvik in 1977-78, Bassholm and Varberg in 1980. Crangon crangon were sampled from the shore line $(0 \mathrm{~m})$ to $0.7 \mathrm{~m}$ depth.

Seasonal variation in temperature (weekly means) was similar at the 4 localities and varied between 4 and $14{ }^{\circ} \mathrm{C}$ in spring and autumn, and between 14 and $20^{\circ} \mathrm{C}$ in summer. During winter (December-March) the areas were usually covered by ice. Salinity, based on daily means recorded each hour, fluctuated between 14 and $24 \%$ S, with extremes between 0 and $30 \% \mathrm{~S}$, especially in autumn. A detailed description of temperature and salinity variability in Gullmarsvik 


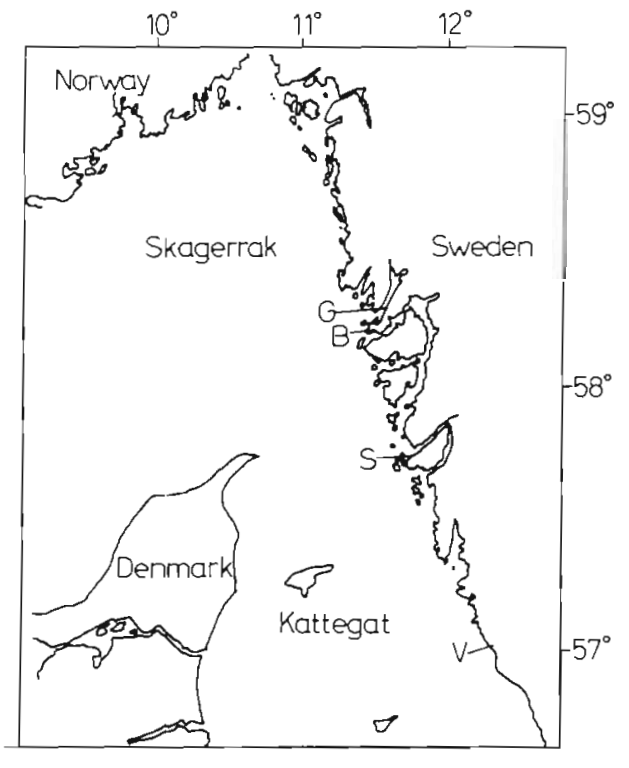

Fig. 1. Location of the areas studied: Gullmarsvik (G), Sandvik (S). Bassholm (B) and Varberg (V)

and Sandvik was given by Pihl and Rosenberg (1982). Tidal amplitude at the localities is $0.1 \mathrm{~m}$, but high pressures, especially in spring, could occasionally drain the areas.

Gullmarsvik and Bassholm face north and are protected from the predominant south-west winds. Sandvik, facing west, is partly-protected by some small islands, whereas Varberg is exposed to winds from the west.
The investigated area in Gullmarsvik covered $15000 \mathrm{~m}^{2}$ of sandy silt sediments with $22 \%(\mathrm{SD}=8)$ sand $(0.2$ to $2.0 \mathrm{~mm}), 72 \%(\mathrm{SD}=7)$ silt $(0.002$ to $0.2 \mathrm{~mm}), 5 \%(\mathrm{SD}=3)$ clay $(<0.002 \mathrm{~mm})$ and organic content of between 0.7 and $2.4 \%$ (all values on weight basis). Sandvik covered $10000 \mathrm{~m}^{2}$ sandy silt sediments with $25 \%(\mathrm{SD}=8)$ sand, $71 \%(\mathrm{SD}=7)$ silt, $3 \%$ $(\mathrm{SD}=1)$ clay and organic content between 0.6 and $1.6 \%$. Bassholm covered $9000 \mathrm{~m}^{2}$ with clay-silt sediments with $6 \%(\mathrm{SD}=2)$ sand $76 \%(\mathrm{SD}=4)$ silt, $18 \%$ $(\mathrm{SD}=2)$ clay and organic content between 2.5 and $9 \%$. The investigated area in Varberg was $10000 \mathrm{~m}^{2}$ with sandy-silt sediments with $29 \%(\mathrm{SD}=2)$ sand, $71 \%(S D=2)$ silt and organic content between 0.4 and $0.5 \%$.

\section{MATERIAL AND METHODS}

\section{Food selection}

Crangon crangon were sampled randomly during daytime with a drop-trap (Pihl and Rosenberg, 1982) 2 to 5 times per month during the ice-free period (April-December) each year. Night sampling in 3 different seasons gave food-selection values similar to those obtained by daytime sampling. Collected shrimp were preserved in $70 \%$ ethanol. Minimum carapace length was measured under a stereo microscope $(12 \times)$ and the shrimp were separated into 7 size classes: Class $1=1.5$ to 2.4 ; Class $2=2.5$ to 3.4 ; etc.; Class 7

Table 1. Crangon crangon. Mean, individual dry weight of dominant meio- and macrofaunal species eaten. (A) Mean dry weight ( $\mu \mathrm{g})$ per individual in meiofauna groups. (B) Relation between dry weight $(\mathrm{mg})$ and length $(\mathrm{mm})(\mathrm{ln} \mathrm{W}=\ln \mathrm{a}+\mathrm{b} \ln \mathrm{L})$ in macrofaunal species

\begin{tabular}{|c|c|c|c|c|c|c|}
\hline \multirow[t]{7}{*}{ (A) } & Meiofauna & & \multicolumn{3}{|c|}{ Weight $(\mu \mathrm{g})$} & Source \\
\hline & Ostracoda & & \multicolumn{2}{|l|}{15} & & B. Widbom (pers. com.) \\
\hline & \multirow[t]{2}{*}{ Harpacticoida } & & 1.7 & & & B. Widbom (pers. com.) \\
\hline & & & $(<1 \mathrm{~mm}$ & & Stripp (1969) \\
\hline & \multirow{2}{*}{\multicolumn{2}{|c|}{ Nematoda }} & $1-2 \mathrm{~mm}$ & \multicolumn{2}{|l|}{0.3} & \\
\hline & & & $>2 \mathrm{~mm}$ & 1.1 & & \\
\hline & \multicolumn{2}{|l|}{ Foraminifera } & \multicolumn{2}{|l|}{1.5} & & Ohlund et al. (1975) \\
\hline \multirow[t]{9}{*}{ (B) } & Macrofauna & a & $b$ & r & $\mathrm{n}$ & \\
\hline & Cardium edule & 0.094 & 3.09 & 0.99 & 40 & Möller \& Rosenberg (1983) \\
\hline & Mytilus edulis & 0.113 & 2.78 & 0.99 & 32 & Loo \& Rosenberg (1983) \\
\hline & Mya arenaria & 0.069 & 2.65 & 0.99 & 42 & Möller \& Rosenberg (1983) \\
\hline & Corophium volutator & 0.006 & 2.70 & 0.99 & 110 & Möller \& Rosenberg (1982) \\
\hline & Bathyporeia pilosa & 0.033 & 1.85 & 0.99 & 10 & L.-E. Persson (pers com.) \\
\hline & - Crangon crangon & 0.420 & 2.85 & 0.99 & 80 & Pihl \& Rosenberg (1982) \\
\hline & - Carcinus maenas & 0.165 & 2.47 & 0.98 & 50 & PihI \& Rosenberg (1982) \\
\hline & Praunus flexuosus & 0.012 & 2.85 & 0.98 & 15 & L. Pihl (unpubl.) \\
\hline
\end{tabular}


$\geqslant 7.5 \mathrm{~mm}$. From each collection, 10 shrimp with stomach contents were randomly selected from each size class. Identifiable prey specimens were counted and measured to the nearest $0.1 \mathrm{~mm}$. The unidentifiable residue was generally insignificant as to weight. Dry weights of the dominant food species were obtained from measurements of average weight (meiofauna) or from length-weight relationships (macrofauna) (Tab. 1). Weights of Nereis spp., however, were determined on individuals found in the stomachs.

\section{Diel food intake}

Diel food intake was determined by taking push-net samples at $2 \mathrm{~h}$ intervals over a $24 \mathrm{~h}$ period on 21 July, 30 August and 11 October, 1977 in Gullmarsvik. From each sample, the number of empty stomachs in a subsample of about 20 specimens of each class, was recorded.

\section{Evacuation rate}

Shrimp, 3 to $8 \mathrm{~mm}$ in carapace length, were sampled with a push-net at $4.45 \mathrm{~h}$ and $5.15 \mathrm{~h}$ on September 1 , 1981 in Gullmarsvik. At these times the proportion of empty stomachs was low. Each sample was divided into 10 groups of 20 shrimp. One group from each sample was immediately preserved in $70 \%$ ethanol, whereas the others were placed in 18 jars $(30 \times 40 \mathrm{~cm})$ containing a $1 \mathrm{~cm}$ layer of washed sand and $15 \mathrm{l}$ filtered sea water. The jars were positioned at a water depth of $10 \mathrm{~cm}$ at the site of capture, thus providing natural temperature $\left(13.5\right.$ to $\left.14.0^{\circ} \mathrm{C}\right)$ and light conditions during the experiment. Subsequently, every half hour the shrimp in one jar from each sample were preserved. In the laboratory their stomachs were weighed (wet wt) with and without contents and the weights of the prey were determined. Stomach content was calculated as percent of body weight (W), and evacuation rate (b) was calculated from the relation$\operatorname{ship} \mathrm{W}=\mathrm{a}+\mathrm{b} \cdot \mathrm{t}$, where $(\mathrm{t})=$ time $(\mathrm{h}) ;(\mathrm{a})=$ intersect.

\section{Food consumption}

Weight of stomach content (as percent of body weight) was estimated every hour from 40 shrimp, 3 to $10 \mathrm{~mm}$ in carapace length. Samples were taken with a push-net during two $8 \mathrm{~h}$ periods in early June 1978, in Sandvik and Gullmarsvik, and during one $24 \mathrm{~h}$ period in early September 1978 in Gullmarsvik. Water temperature during experiments was 12 to $13{ }^{\circ} \mathrm{C}$ in June and 12 to $14{ }^{\circ} \mathrm{C}$ in September. Food consumption during these periods was calculated as:

$$
C=\sum_{t=0}^{t=n} W_{t+1}-W_{t} \cdot b
$$

where $\mathrm{C}=$ food consumption as percent of body weight; $\mathrm{W}_{\mathrm{t}}=$ mean weight of stomach content as percent of body weight; $b=$ evacuation rate calculated from $W=a+b \quad t$.

\section{Sediment analysis}

Grain size and organic carbon of the sediment were analysed by taking $15 \mathrm{~cm}^{2}$ cores down to $5 \mathrm{~cm}$ depth at 4 to 18 randomly chosen sites every second month. Grain size was determined after sieving in 9 different sieves $(0.074$ to $64 \mathrm{~mm})$ and by sedimentation rate $(0.002$ to $0.74 \mathrm{~mm})$. Organic content was determined after drying at $60^{\circ} \mathrm{C}$ and ignition for $5 \mathrm{~h}$ at $550^{\circ} \mathrm{C}$.

\section{RESULTS}

\section{Food selection}

Temporal and spatial variation

In Gullmarsvik, Sandvik and Bassholm, ostracods were, by weight, the dominant meiofaunal group eaten, followed by harpacticoids (Fig. 2). At all localities, nematodes and foraminiferans were of lesser importance.

In terms of weight, Nereis spp. and Corophium volutator were the main macrofauna items eaten in most years in Gullmarsvik, Sandvik and Bassholm. In Sandvik, Nereis were the dominant food component, especially in 1977, whereas C. volutator was most important in Gullmarsvik in 1977-78 and in Bassholm in 1980. In 1979, however, 0-group bivalves (Mya arenaria, Cardium [ = Cerastoderma] edule, Mytilus edulis) were the preferred food of Crangon crangon in Gullmarsvik. That year they contributed about $80 \%$ by weight of all food eaten by shrimp larger than Sizeclass 2. In 1978 these bivalves and Spisula subtruncata provided (by weight) half of the food for shrimp in the Size-classes 4 to 6 at this locality. At the other localities bivalves were of less importance during the investigation.

Mobile species were also eaten by Crangon crangon. In 1977 newly settled (1 to 4 post-larval moults) $C$. crangon played an important role as food for shrimp of Size-classes 4 to 7 in Gullmarsvik, and in 1978 recently settled Carcinus maenas were consumed. In 1977, in Sandvik, mysids comprised an important component of the shrimp diet.

At the exposed sandy locality, Varberg, harpac- 
ticoids were the dominant meiofaunal food item, followed by ostracods. The mysid Praunus flexousus and the amphipod Bathyporeia pilosa were the preferred macrofauna prey. Other species or groups eaten in the study areas were Hydrobia spp., Bitium sp., Littorina sp., Balanus sp., Tellina sp., Gammarus sp., other amphipods, polychaetes and oligochaetes.
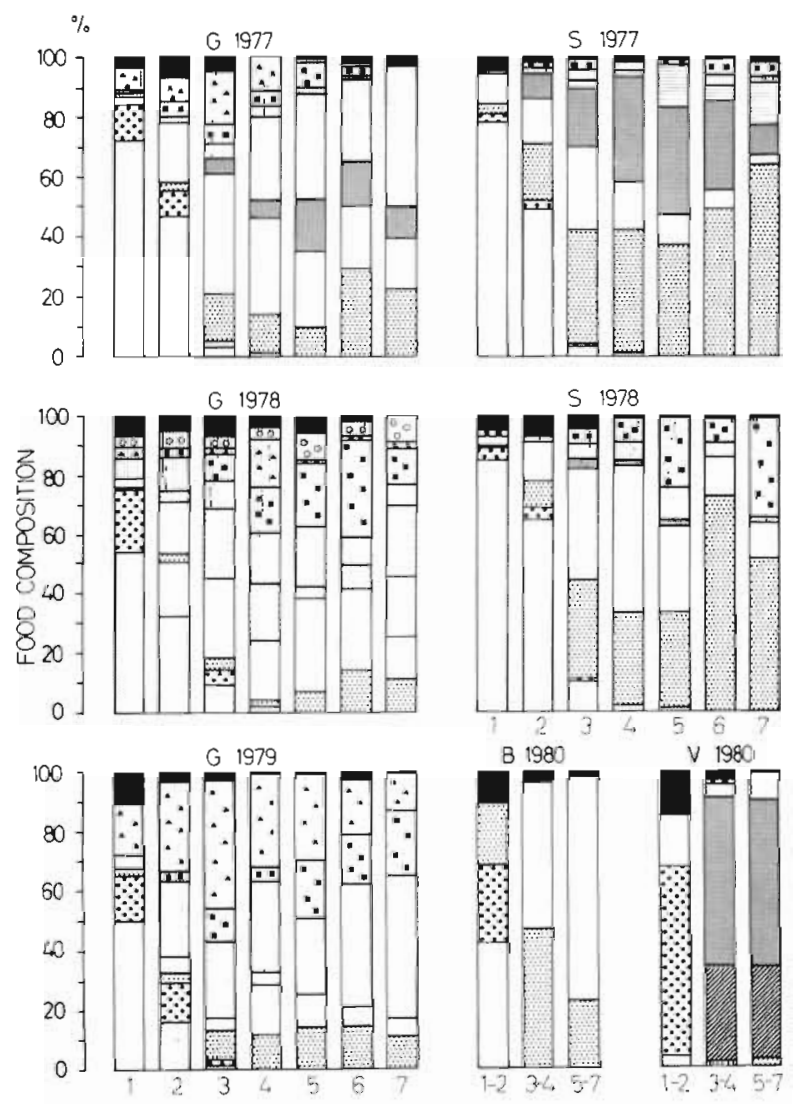

SIZF-CLASSES

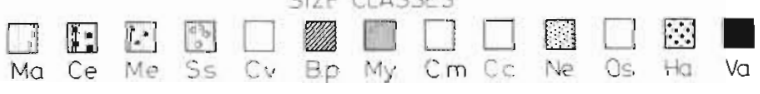

Fig. 2. Crangon crangon. Food composition expressed as weight percentages in relation to shrimp size-classes in Gullmarsvik (G) 1977-1979, Sandvik (S) 1977-1978, Bassholm (B) 1980 and Varberg (V) 1980. Mya arenaria (M. a.), Cardium edule (C. e.), Mytilus edulis (M. e.), Spisula subtruncata (S. s.), Corophium volutator (C. v.), Bathyporeia pilosa (B. p.), Mysidae (M. y.), Carcinus maenas (C. m.), Crangon crangon (C. c.), Nereis spp. (Ne.), Ostracoda (Os.), Harpactiocoida (Ha.) and Various (Va.)

While fragments of algae and sand grains were found in small amounts in the stomach of Crangon crangon from all localities examined, their weight was not recorded. Total number of species or genera identified in the stomachs of $C$. crangon were 24, 19, 9 and 14 in Gullmarsvik, Sandvik, Bassholm and Varberg, respectively.

\section{Prey in relation to shrimp size}

Meiofauna, mainly ostracods and harpacticoids, were the principal food for Class 1 and 2 shrimp (Fig. 2). With increased length, Crangon crangon switched to macrofauna, first Nereis spp., Corophium volutator and bivalves, and later (in some years), to

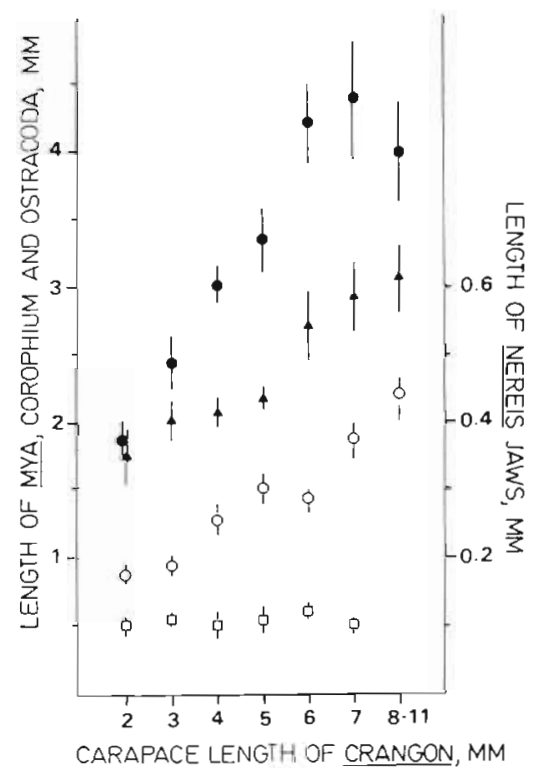

Fig. 3. Crangon crangon. Body size in relation to size (mean and S. E.) of 4 dominant food items: Nereis spp. (4), Mya

arenaria (O), Corophium volutator $(\bullet)$ and Ostracoda $(\square)$

larger crustaceans (e.g. Crangon crangon, Carcinus maenas and mysids). The sizes of meiofaunal prey eaten were not related to shrimp size (Fig. 3), except for nematodes. Nematodes and all macrofauna prey species were positively related to shrimp size; Fig. 3 shows this for Nereis spp., C. volutator and Mya arenaria.

\section{Seasonal variation}

The seasonal variation in food composition was similar at all localities and, therefore, this is only shown for Gullmarsvik during 1977-1979 (Fig. 4). Meiofauna was preferred by Size Class 1-2 shrimp (Fig. 4A), but was also taken by Size Class 3-4 (Fig. 4B), especially during spring and autumn. Nereis spp. and Corophium volutator were eaten by all size classes at all seasons, but were particularly important for intermediate and large-sized shrimp during spring and autumn. 0-group bivalves were the main food for all size classes in July and August, and in 1979 they continued to be so until 


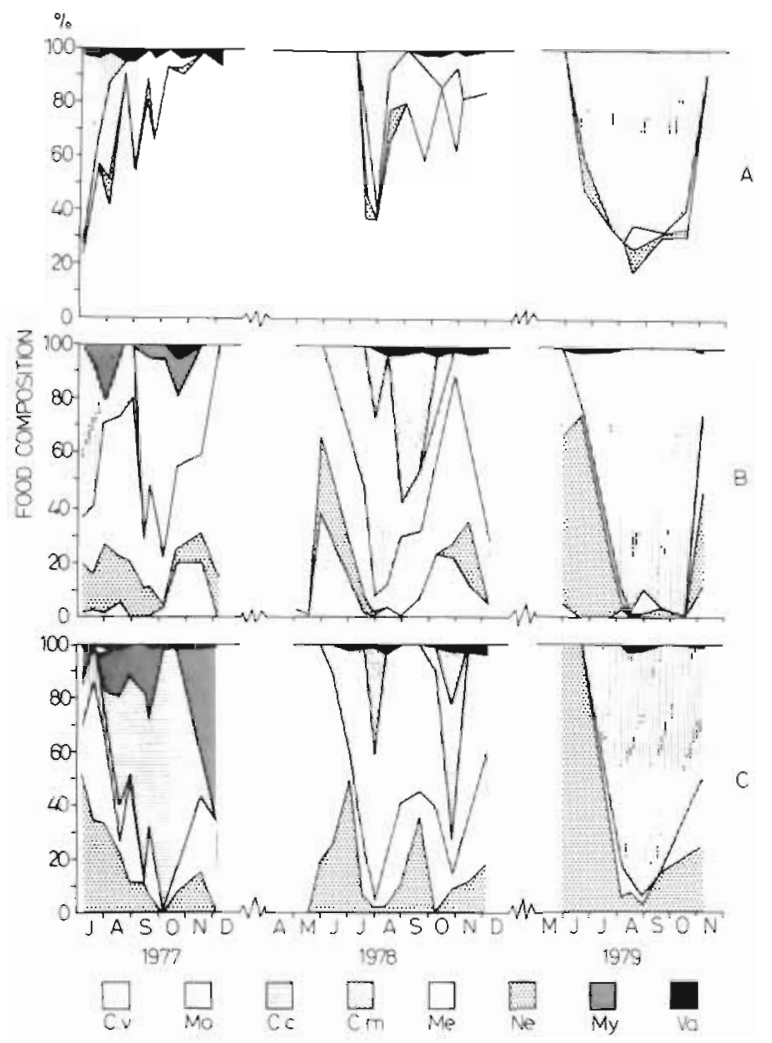

Fig. 4. Crangon crangon. Seasonal variation in food composition as weight percentages in 3 size-classes (1-2 = A, 3-4 = B, 5-7 = C) in Gullmarsvik 1977-1979. Corophium volutator (C. v.), Mollusca (Mo.), Crangon crangon (C. C.), Carcinus maenas (C. m.), meiofauna (Me.), Nereis spp. (Ne.), Mysidae (My.), various (Va.)

the end of October. The relative composition of the dominant bivalves Mya arenaria, Cardium edule and Mytilus edulis in the food did not vary by season. In autumn 1978, Spisula subtruncata and Tellina sp. were also taken. In 1977, Crangon crangon and mysidae, and in 1978 Carcinus maenas, were preyed upon by middle-sized and large shrimp during late summer and autumn.

\section{Food consumption}

\section{Diel food intake}

The lowest relative number of empty stomachs was obtained during darkness with minima around dawn and dusk (Fig. 5). In summer, with extended light periods, a low proportion of empty stomachs was also obtained around mid-day. The average proportion of empty stomachs was lower in autumn $(26 \%)$ than in summer ( 33 to $36 \%$ ). In June 1978, the mean percentage for empty stomachs in samples taken over a $12 \mathrm{~h}$ period ( 12.00 to $24.00 \mathrm{~h}$ ) was $54 \%$.

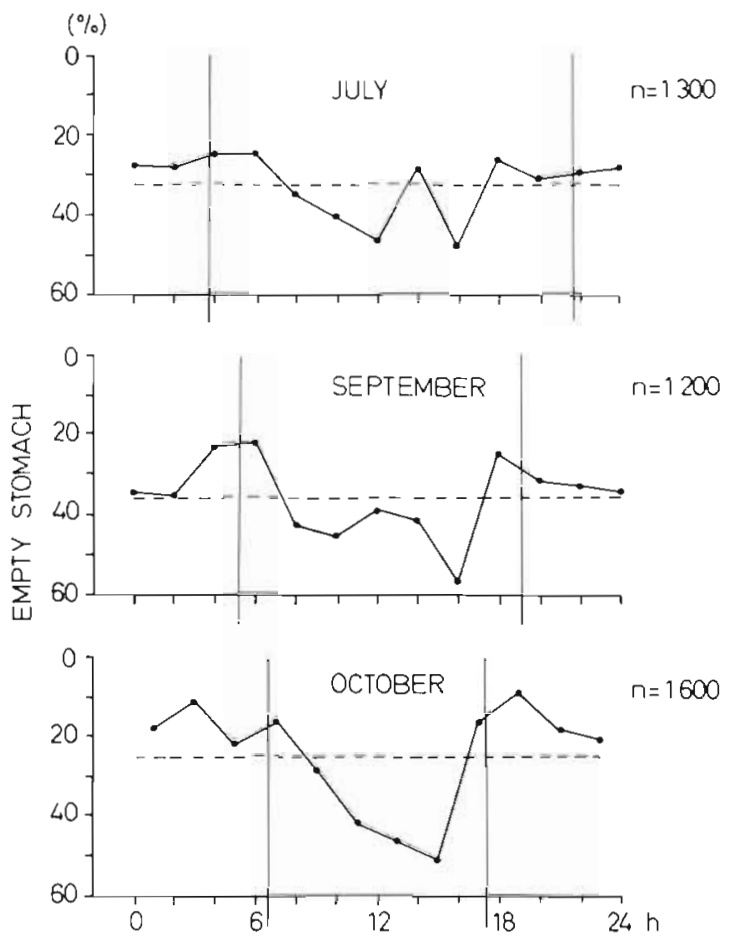

Fig. 5. Crangon crangon. Empty stomachs (\%) in the population examined every second hour (and mean values - . -) during three $24 \mathrm{~h}$ periods in Gullmarsvik 1977. Sunrise and sunset indicated by vertical lines

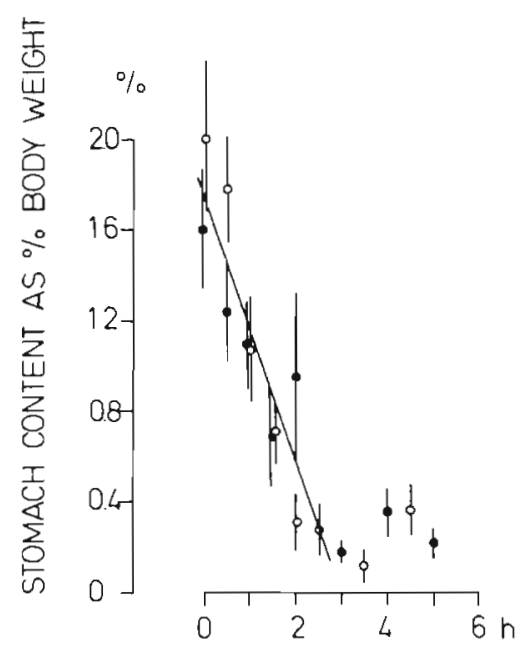

Fig. 6. Crangon crangon. Evacuation of stomach content (mean and S. E.) as function of time in individuals of 3 to $8 \mathrm{~mm}$ carapace length. Means of 2 experiments ( $O$ and $\bullet$ ) carried out in Gullmarsvik 1981. Experiments were started at 4.45 and $5.15 \mathrm{~h}$ which have been set at time zero. The regression from time $0-4 \mathrm{~h}$ is $\mathrm{Y}=4.6+0.58 \mathrm{x}_{;} \mathrm{r}=0.92$

\section{Evacuation rate}

Evacuation rate was approximately negatively linear with time, at least during the 2 first $h$ of the experiments (Fig. 6). The rates were similar in the 2 experi- 
ments, and a common regression was calculated from mean rates relating to stomach content of $0.3 \%$ body weight and above. Below this minimum value, most of the food was considered to be digested and the main residue was sand grains. For this reason, values of Wt $\cdot \mathrm{b}<0.3 \%$ (see Material and Methods) were set equal to 0.3 . In this way, mean evacuation rate was estimated as $0.58 \%$ of the population mean body weight per hour.

\section{Consumption}

In early September, the actual stomach contents of Crangon crangon were higher in the night than in the day (Fig. 7). Highest values were found at dawn and dusk, but the stomach content increased to a minor peak also at noon. Between 7.00 and 8.00 and between 12.00 and 14.00 food intake was nil or very low, as the slope or the curve in Fig. 7 was similar to that of the digestion rate (cf. Fig. 6). From 8.00 to 12.00 and from

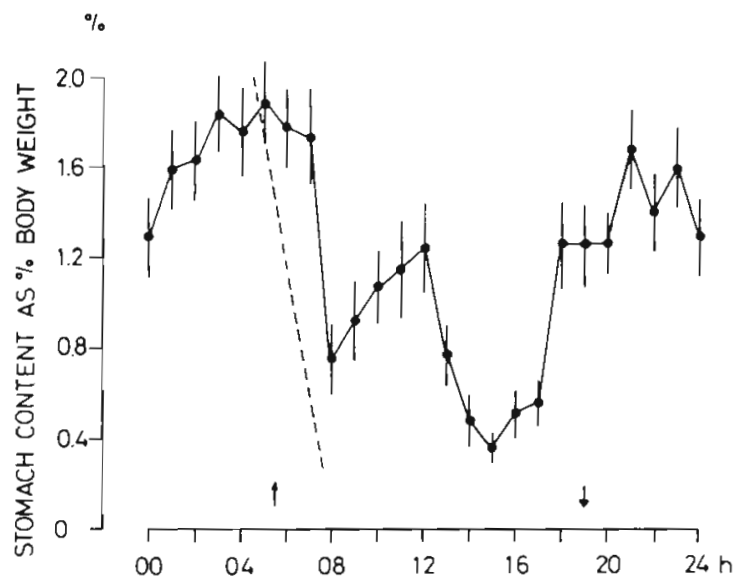

Fig. 7. Crangon crangon. Weight of stomach content (mean and S. E.) in individuals of 3 to $10 \mathrm{~mm}$ carapace length during a $24 \mathrm{~h}$ period in early September in Gullmarsvik 1978. Evacuation rates (- - ) from Fig. 6 are included. Sunrise and sunset indicated by arrows

17.00 to 18.00 an increased food intake was observed. Total food intake during the $24 \mathrm{~h}$ period was estimated to be $12.1 \%$ of the body wet weight. During the $24 \mathrm{~h}$ period, $77 \%$ of the consumption occurred between dusk and dawn (17.00 to $07.00 \mathrm{~h})$. During that period consumption rate amounted to an hourly average of $0.7 \%$ of body weight. In early June, food intake of overwintered shrimps over the $8 \mathrm{~h}(14.00-22.00)$ was estimated to be $3.3 \%$ in Gullmarsvik and $3.1 \%$ in Sandvik. Considering these periods to be representative for $1 / 3$ of the 24 h period, the daily intake would be about $10 \%$ of the body weight. From Fig. 7 it is apparent, however, that most food was eaten before sunrise and that $10 \%$ may be an underestimate for that $24 \mathrm{~h}$ period, suggesting $12.1 \%$ as the most probable estimate for June and September.

\section{DISCUSSION}

\section{Food selection}

In shallow waters of western Sweden the main food items taken by Crangon crangon belonged to the infauna. The food was selected according to size, i.e. larger shrimp ate larger prey, but apart from that, food items were taken approximately in relation to their relative occurrence. Therefore, food composition changed with the seasonal changes of infauna in the area and $C$. crangon could be considered as a carnivorous opportunist (Wilcox and Jeffries, 1974). On the partly sheltered localities with sandy silt sediments (Gullmarsvik and Sanvik), medium and large C. crangon preyed mainly upon Mya arenaria, Cardium edule, Nereis diversicolor and Corophium volutator; the 2 latter species were the principal food items on the clay-silt bottom (Bassholm). In the exposed, sandy-silt locality (Varberg) the main infaunal species taken was Bathyporeia pilosa. Thus, sediment structure and exposure influence infaunal composition and, thereby, food composition.

Crangon crangon also ate semi-pelagic mysid species, especially at the exposed locality. Large shrimp were cannibals, especially in Gullmarsvik in 1977, a time and eating habit which seem to have coincided with low recruitment of Mya arenaria and Cardium edule (Möller and Rosenberg, 1983) and of Corophium volutator (Möller and Rosenberg, 1982) and a high abundance of postlarval C. crangon. Hence, lack of food among the infauna in the area during that year could be the reason for the cannibalism. In the Elbe estuary the main food items were amphipods and worms, but larger $C$. crangon were also cannibals (Plagmann, 1939). This author reported that C. crangon also ate a high proportion of detritus a component which was insignificant in this study.

\section{Diel food intake}

The main feeding period was during darkness with peaks of feeding around dawn and dusk. In summer, a secondary feeding period occurred during the day. Similar patterns of activities, confined principally to the dark period, were recorded by Hagerman (1970), Dyer and Uglow (1978) and van Donk and de Wilde (1981). An additional mid-day peak in summer, as in this study, was found for Crangon septemspinosa (Wilcox and Jeffries, 1974). However, part of the C. crangon 
population in this study was also eating between the peak periods (Fig. 5), e.g. during the long-day period in summer.

\section{Evacuation rate}

Evacuation rate exhibited a negative linear relation with time, similar to the decrease in stomach content in the Gullmarsvik population in September between 7.00 and $8.00 \mathrm{~h}$ and between 12.00 and $14.00 \mathrm{~h}$ (Fig. 7). Thus, at these hours feeding rate was minimal. The food left the stomach within $2 \mathrm{~h}$; a similar rapid passage of $1 \mathrm{~h}$ was recorded for Crangon septemspinosa (Wilcox and Jeffries, 1974). Our estimate was a mean for the whole population; evacuation rates for small and large shrimp are higher and lower, respectively (van Lissa, 1977). Moreover, the experiments were made with confined and non-feeding animals, which could have had some impact on the results.

\section{Consumption}

The mean diel food intake by Crangon crangon in Gullmarsvik and Sandvik in June and September was estimated to be $12.1 \%$ of body wet weight. That percentage was obtained at 12 to $14{ }^{\circ} \mathrm{C}$. It is of great interest to calculate the annual consumption, which comprises the ice-free period from April to December. We feel that such an estimate could be made with confidence, and for the 1979 results is used as an example with data from Pihl and Rosenberg (1982). In 1979 the mean temperature during the ice-free period was $11.3^{\circ} \mathrm{C}$, calculated from weekly means. Of the annual production of C. crangon, $88 \%$ occurred between 10 and $16{ }^{\circ} \mathrm{C}$. A change in temperature of $1 \mathrm{C}^{\circ}$ in that interval, from the experimental temperatures 12 to $14{ }^{\circ} \mathrm{C}$, will change the food intake by $4 \%$ for the largest and by $8 \%$ for the smallest shrimp, based on calculations from van Lissa (1977). At higher and lower temperatures food intake will be higher and lower, respectively, and these differences will to some degree compensate each other.

Another possibility for calculating annual consumption is to use van Lissa's (1977) results of temperaturedependent food intake and adjust the diel food intake of $12.1 \%$ of body weight accordingly for each sampling date. The mean change in food intake by the shrimp population will then be about $6 \%$ for a $1 \mathrm{C}^{\circ}$ change in temperature between 10 and $20^{\circ} \mathrm{C}$. Such

Table 2. Crangon crangon. Annual food consumption allocated to dominant macrofaunal species and total meiofauna in the investigated areas during 1977-80. All figures are $\mathrm{mg} \mathrm{AFDW} \mathrm{m}{ }^{-2}$; in brackets: percent of total consumption

\begin{tabular}{|c|c|c|c|c|c|c|c|}
\hline & \multicolumn{3}{|c|}{ Gullmarsvik } & \multicolumn{2}{|c|}{ Sandvik } & \multirow{2}{*}{$\begin{array}{c}\text { Bassholm } \\
1980\end{array}$} & \multirow{2}{*}{$\begin{array}{c}\text { Varberg } \\
1980\end{array}$} \\
\hline & 1977 & 1978 & 1979 & 1977 & 1978 & & \\
\hline Nereis spp. & $\begin{array}{l}3394 \\
(24.4)\end{array}$ & $\begin{array}{c}1079 \\
(8.7)\end{array}$ & $\begin{array}{c}1392 \\
(9.4)\end{array}$ & $\begin{array}{l}5475 \\
(47.9)\end{array}$ & $\begin{array}{l}5801 \\
(44.3)\end{array}$ & $\begin{array}{c}774 \\
(20.7)\end{array}$ & \\
\hline Corophium volutator & $\begin{array}{l}3338 \\
(24.0)\end{array}$ & $\begin{array}{l}3605 \\
(29.1)\end{array}$ & $\begin{array}{l}650 \\
(4.4)\end{array}$ & $\begin{array}{l}884 \\
(7.7)\end{array}$ & $\begin{array}{l}3744 \\
(28.6)\end{array}$ & $\begin{array}{c}1569 \\
(42.1)\end{array}$ & $\begin{array}{c}1300 \\
(15.0)\end{array}$ \\
\hline Mya arenaria & $\begin{array}{l}139 \\
(1.0)\end{array}$ & $\begin{array}{l}1303 \\
(10.5)\end{array}$ & $\begin{array}{l}4491 \\
(30.4)\end{array}$ & $\begin{array}{l}270 \\
(2.3)\end{array}$ & $\begin{array}{l}514 \\
(3.9)\end{array}$ & & $\begin{array}{l}1297 \\
(14.9)\end{array}$ \\
\hline Cardium edule & $\begin{array}{l}357 \\
(2.5)\end{array}$ & $\begin{array}{l}1330 \\
(10.8)\end{array}$ & $\begin{array}{l}1720 \\
(11.7)\end{array}$ & $\begin{array}{l}486 \\
(4.2)\end{array}$ & $\begin{array}{c}1104 \\
(8.4)\end{array}$ & & $\begin{array}{c}98 \\
(1.1)\end{array}$ \\
\hline Mytilus edulis & $\begin{array}{l}278 \\
(2.0)\end{array}$ & $\begin{array}{l}187 \\
(1.5)\end{array}$ & $\begin{array}{l}3310 \\
(22.4)\end{array}$ & & & & \\
\hline Crangon crangon & $\begin{array}{l}3325 \\
(23.9)\end{array}$ & $\begin{array}{l}487 \\
(3.9)\end{array}$ & $\begin{array}{l}274 \\
(1.8)\end{array}$ & $\begin{array}{l}631 \\
(5.5)\end{array}$ & & & \\
\hline Mysidae & $\begin{array}{l}1808 \\
(13.0)\end{array}$ & & & $\begin{array}{l}2982 \\
(26.0)\end{array}$ & & & $\begin{array}{l}3109 \\
(35.8)\end{array}$ \\
\hline Carcinus maenas & $\begin{array}{l}126 \\
(0.9)\end{array}$ & $\begin{array}{l}1906 \\
(15.4)\end{array}$ & $\begin{array}{l}454 \\
(3.0)\end{array}$ & & & & \\
\hline Bathyporeia pilosa & & & & & & & $\begin{array}{l}2192 \\
(25.4)\end{array}$ \\
\hline Meiofauna (total) & $\begin{array}{l}639 \\
(4.6)\end{array}$ & $\begin{array}{l}990 \\
(8.0)\end{array}$ & $\begin{array}{l}914 \\
(6.2)\end{array}$ & $\begin{array}{l}511 \\
(4.5)\end{array}$ & $\begin{array}{l}1609 \\
(12.3)\end{array}$ & $\begin{array}{l}1285 \\
(34.4)\end{array}$ & $\begin{array}{l}645 \\
(7.5)\end{array}$ \\
\hline Various & $\begin{array}{l}517 \\
(3.7)\end{array}$ & $\begin{array}{l}1510 \\
(12.2)\end{array}$ & $\begin{array}{l}1578 \\
(10.7)\end{array}$ & $\begin{array}{l}217 \\
(1.9)\end{array}$ & $\begin{array}{l}319 \\
(2.4)\end{array}$ & $\begin{array}{c}103 \\
(2.8)\end{array}$ & $\begin{array}{c}25 \\
(0.3)\end{array}$ \\
\hline Total food consumed & 13921 & 12397 & 14783 & 11456 & 13091 & 3731 & 8666 \\
\hline
\end{tabular}


calculation for Gullmarsvik results in an annual consumption of 14.4 and $12.3 \mathrm{~g} \mathrm{AFDW} \mathrm{m}^{-2}$ in 1979 and 1980, respectively. These values are similar to 14.8 and $11.6 \mathrm{~g} \mathrm{AFDW} \mathrm{m}^{-2}$, respectively, as obtained when a $12.1 \%$ diel food intake is used for the whole season. Thus, this percentage seems to give accurate estimates of annual consumption in this temperature regime and, therefore, $12.1 \%$ have been used in the calculations presented here.

The calculations were made on a wet-weight basis, because the stomachs of the young shrimp were too small for accurate AFDW determinations. However, the total food intake in the investigated areas could be estimated in AFDW terms by assuming that the percentage food intake is approximately the same in wet weight as in AFDW. The total food intake in Gullmarsvik and Sandvik was estimated using the mean biomass of the shrimp population (Pihl and Rosenberg, 1982), sampled over approximately 2 wk periods from April to December and multiplied by the rate of food intake $\left(12.1 \% \mathrm{~d}^{-1}\right)$ during each period. Similar quantitative investigations were made in Bassholm and Varberg (unpubl.); results from these 4 areas are shown in Table 2 . The proportional allocation of different prey species was estimated from data on mean food percentage composition of each species in the stomachs during each period, multiplied by total food intake. The relation between wet weight and AFDW is probably slightly greater for the food items than for $C$. crangon, because non-digestible materials - such as shells and sand grains - are included in the food wetweight calculations; this may result in overestimation of the intake.

Food conversion $(\mathrm{P} / \mathrm{C})$ values were estimated from production estimates for Gullmarsvik (1977-1979) and Sandvik given by Pihl and Rosenberg (1982), and for Gullmarsvik (1980-1982) by Bassholm and Varberg in an extension of that study with the same methods (unpubl.). Consumption was estimated in the present investigation. Food conversion values were fairly similar (16 to $22 \%$ ) among years and areas (Table 3$)$, with ca. $19 \%$ as a mean. This is about half of the value of $35 \%$ given by Kuipers and Dapper (1981) or the $39 \%$ calculated by Meixner (1966). The 2 latter values were obtained from laboratory experiments, where Crangon crangon in the first experiment were under ad libitum feeding conditions and in the second experiment were given the nutritious Artemia as food.

In this study, consumption was highest in Gullmarsvik (11.6 to $14.8 \mathrm{~g} \mathrm{AFDW} \mathrm{m}^{-2} \mathrm{yr}^{-1}$ ) and in Sandvik (11.4 to 13.1 AFDW m-2 $\mathrm{yr}^{-1}$ ). In these 2 areas the shrimp were most abundant and the highest biomass values were generally found between mid August and mid October at temperatures between 10 and $16{ }^{\circ} \mathrm{C}$ (Pihl and Rosenberg, 1982). Calculated over that 2 mo
Table 3. Crangon crangon. Annual mean biomass $(\overline{\mathrm{B}})$, production (P) and food consumption (C) in the investigated areas 1977-1982. All figures are g AFDW m ${ }^{-2}$. Biomass and production figures from Pihl and Rosenberg (1982) and unpubl. own results

\begin{tabular}{|lcccccc|}
\hline Area & Year & $\overline{\mathrm{B}}$ & $\mathrm{P}$ & $\mathrm{C}$ & $\mathrm{P} / \overline{\mathrm{B}}$ & $\mathrm{P} / \mathrm{C}$ \\
\hline Gullmarsvik & 1977 & 0.67 & 3.1 & 13.9 & 4.6 & 0.22 \\
& 1978 & 0.41 & 2.2 & 12.4 & 5.4 & 0.18 \\
& 1979 & 0.53 & 2.3 & 14.8 & 4.4 & 0.16 \\
& 1980 & 0.36 & 2.3 & 11.6 & 6.4 & 0.20 \\
& 1981 & 0.57 & 2.2 & 12.0 & 3.9 & 0.18 \\
& 1982 & 0.57 & 2.5 & 14.7 & 4.4 & 0.17 \\
Sandvik & 1977 & 0.57 & 2.3 & 11.4 & 3.9 & 0.20 \\
& 1978 & 0.41 & 2.6 & 13.1 & 6.4 & 0.20 \\
Bassholm & 1980 & 0.17 & 0.7 & 3.7 & 3.9 & 0.19 \\
& 1981 & 0.21 & 0.8 & 4.1 & 3.6 & 0.20 \\
Varberg & 1980 & 0.34 & 1.4 & 8.7 & 4.1 & 0.16 \\
& & & & & & \\
\hline
\end{tabular}

period, approximately $50 \%$ of the total annual consumption occurred (Fig. 8). Mean monthly food intake during that peak-biomass period ranged between 3.0 and $4.0 \mathrm{~g} \mathrm{AFDW} \mathrm{m}^{-2}$.

In the Wadden Sea the most intensive production period of $C$. crangon was during August and September (Reise, 1977). The shrimp's mean annual consumption (April-October) in that region was estimated to be $6.7 \mathrm{~g} \mathrm{AFDW} \mathrm{m}^{-2}$, based on the food conversion of

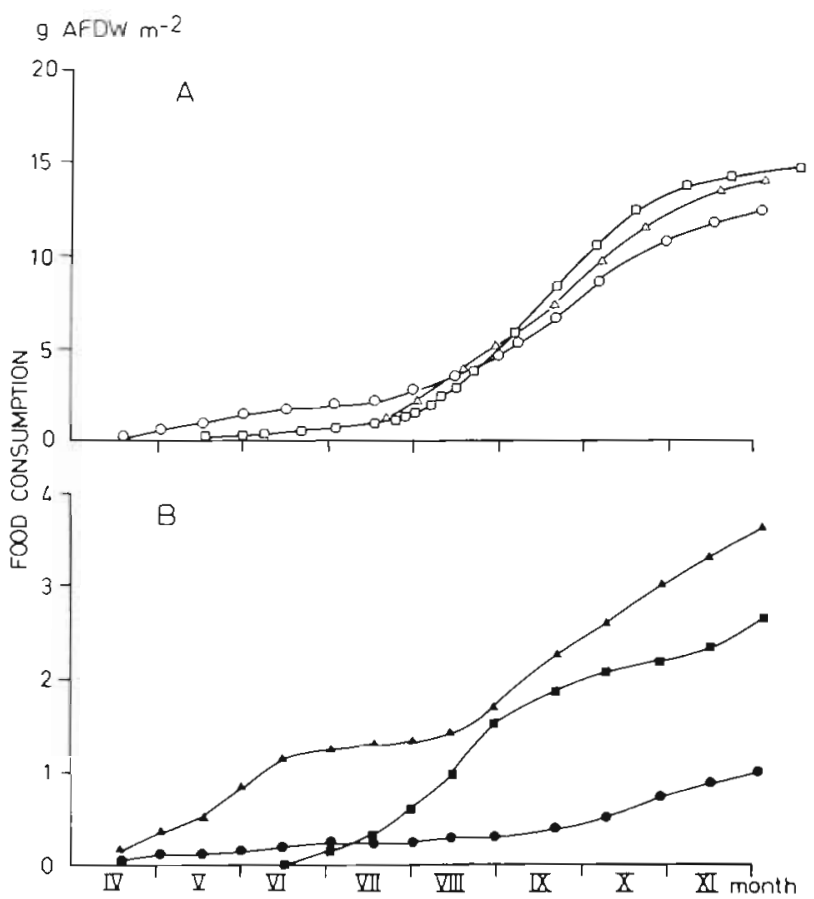

Fig. 8. Crangon crangon. Cumulative annual food consumption (g AFDW $\mathrm{m}^{-2} \mathrm{yr}^{-1}$ ) in Gullmarsvik. (A) Total consumption $1977(\Delta), 1978$ (O) and 1979 (口). (B) Consumption of Corophium volutator (\$), Mya arenaria and Cardium edule (•) and meiofauna (•) in 1978 
$35 \%$ (Kuipers and Dapper, 1981). This consumption was much lower than at our sandy-silt localities. However, if the mean food conversion factor of $19 \%$ is applied, as based on our field investigations, a mean consumption of about $13 \mathrm{~g}$ AFDW $\mathrm{m}^{-2}$ results, i.e. a similar consumption for both areas. In another study of the Wadden Sea area, the annual shrimp consumption

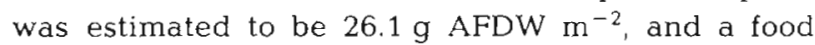
conversion factor of $12 \%$ was adopted yielding an annual production of $3.1 \mathrm{~g}$ AFDW $\mathrm{m}^{-2}$ (van Lissa, 1977). That consumption estimate was higher than in this study, mainly because the production was higher and the conversion factor used was lower than that used in our studies.

\section{Consumption in relation to benthos}

In the cumulative total annual consumption of Crangon crangon (1977-1979, Gullmarsvik, Fig. 8A), there was a slow increase from April through July, followed by a higher consumption toward the end of autumn. This high consumption was mainly due to the high biomass of 0 -group shrimp at that time (Pihl and Rosenberg, 1982). In spring, $C$. crangon consumed mainly Corophium volutator (Fig. 8B), as this species recolonized the area shortly after break up of the ice (Möller and Rosenberg, 1982). From July, C. crangon turned to 0-group bivalves Mya arenaria and Cardium edule, which were its main food items in subsequent months. Meiofauna was taken mainly in early summer and late autumn.

Production estimates of infauna were given by Möller and Rosenberg (1982, 1983; unpubl.) and of epifauna by Pihl and Rosenberg (1982; unpubl.). The annual consumption of Crangon crangon is compared with these production figures (Table 4). In Gullmarsvik, C. crangon annually consumed 10 to $121 \%$ of the production of Nereis spp., 25 to $97 \%$ of the Corophium volutator production and 2 to $68 \%$ of the production of the bivalves Mya arenaria and Cardium edule. In Sandvik 10 to $90 \%$ of the production of Nereis spp. and $C$. volutator were consumed. Thus, it can be concluded that $C$. crangon is one of the major carnivores in these shallow areas and exerts a major impact on the infaunal community. C. crangon were also one of the main predators in the intertidal zone of the Wadden Sea (Reise, 1977). In that region Kuipers and Dapper (1981) regarded the macrobenthic food as just enough to support the predators including the most important carnivore $C$. crangon.

Crangon crangon also preyed upon juvenile Carcinus maenas and its own offspring. The annual consumption of the production of these 2 species was from $13 \%$ up to more than $100 \%$. The reason why the calculations show that $C$. crangon might consume more than its own production and more than the production of other species is probably because consumption was slightly overestimated, as mentioned earlier and/or that production was underestimated. This is suggested because $C$. crangon consumes recently recruited $C$. maenas and $C$. crangon; almost exclusively, the smallest size class of these prey items were found in the stomachs. These larval and postlarval stages were transported to shallow waters intermittently throughout the summer and early autumn. Obviously, many were also eaten between the sampling intervals of 1 to $2 \mathrm{wk}$ in the production studies and are excluded from production calculations. The true production of $C$. crangon and C. maenas should have been higher, but the underestimation is probably only a matter of a few percent, as the majority was eaten shortly after recruitment and their total biomass was low. On the other hand, the discrepancy demonstrates that we deal with an open system and that food is supplied from surrounding waters. The consumption

Table 4. Crangon crangon. Annual consumption of C. crangon and annual production of some benthic infauna and mobile epifauna species in Gullmarsvik and Sandvik 1977-79. All values are AFDW $\mathrm{m}^{-2} \mathrm{yr}^{-1}$ Consumption, as percent of production, is given in parentheses. Production estimates from Möller and Rosenberg (1982, 1983), Pihl and Rosenberg (1982), and Möller (unpubl.)

\begin{tabular}{|c|c|c|c|c|c|c|c|}
\hline \multirow[t]{2}{*}{ Area } & \multirow[t]{2}{*}{ Species } & \multicolumn{3}{|c|}{ Production } & \multicolumn{3}{|c|}{ Consumption } \\
\hline & & 1977 & 1978 & 1979 & 1977 & 1978 & 1979 \\
\hline \multirow{6}{*}{ Gullmarsvik } & Nereis spp. & 2.8 & 11.2 & 8.9 & $3.4(121)$ & $1.1(10)$ & $1.4(16)$ \\
\hline & Corophium volutator & 3.4 & 6.3 & 2.8 & $3.3(97)$ & $3.6(57)$ & $0.7(25)$ \\
\hline & Mya arenaria (0-group) & 2.3 & 3.6 & 218.0 & $0.1(5)$ & $1.3(36)$ & $4.5(2)$ \\
\hline & Cardium edule (0-group) & 3.6 & 1.9 & 43.0 & $0.4(11)$ & $1.3(68)$ & $1.7(4)$ \\
\hline & Crangon crangon & 3.1 & 2.2 & 2.3 & $3.3(106)$ & $0.5(23)$ & $0.3(13)$ \\
\hline & Carcinus maenas & 0.4 & 1.8 & 1.5 & $0.1(25)$ & $1.9(105)$ & $0.5(33)$ \\
\hline \multirow[t]{3}{*}{ Sandvik } & Nereis spp. & 52.8 & 17.0 & & $5.5(10)$ & $5.8(34)$ & \\
\hline & Corophium volutator & 2.6 & 4.1 & & $0.9(35)$ & $3.7(90)$ & \\
\hline & Crangon crangon & 2.3 & & & $0.6(26)$ & & \\
\hline
\end{tabular}


estimates for Nereis spp. Concerns all species of this genera, but the production refers to Nereis diversicolor only (Table 4) and this could explain why consumption exceeded production in 1977.

Although Crangon crangon probably was the main predator in Gullmarsvik during 1977-1982 and consumed a high amount of the production of infauna and epifauna, it is unlikely that food was a limiting growth factor for the mid- and large-size classes. This is suggested, because the annual production was similar

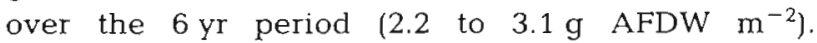
Moreover, in 1977, when infaunal biomass seemed to be low, C. crangon switched to epifauna as the main food constituent.

Acknowledgements. We sincerely thank our colleagues Ms. B. Bengtsson and $\mathrm{Mr}$. M. Ulmestrand for valuable assistance and Mrs. S. Baden, Dr. L. Hagerman, Mr. P. Möller, and Dr. W. Wolff for their critical review of this paper. Dr. R. Uglow also helped us to improve the style of the manuscript. Financial support was given by the Swedish Environmental Protection Board.

\section{LITERATURE CITED}

Donk, E. van, de Wilde, P. A. W. J. (1981). Oxygen consumption and motile activity of the brown shrimp Crangon crangon related to temperature and body size. Neth. J. Sea Res. 15: 54-64

Dyer, M. F., Uglow, R. F. (1978). Heart and scaphognathite beat behaviour in laboratory-held Crangon crangon (L.). J. exp. mar. Biol. Ecol. 32: 209-218

Hagerman, L. (1970). Locomotory activity patterns of Crangon vulgaris (Fabricius) (Crustacea, Natantia). Ophelia 8: 255-256

Kuipers, B. R., Dapper, R. (1981). Production of Crangon crangon in the tidal zone of the Dutch Wadden Sea. Neth. J. Sea Res. 15: 33-53

Lissa, J. H. L. van (1977). Aantallen, voedselopname, groei en produktie van de gamaal (Crangon crangon L.) in een getijdengebied, alsmede de voedselopname en groei on der laboratoriumomstandigheden. Interne Verslagen Netherlands Instituut voor Onderzoek der Zee 10: 1-101

Loo, L.-O., Rosenberg, R. (1983). Mytilus edulis culture: growth and production in western Sweden. Aquaculture 35: $137-150$

Meixner, R. (1966). The effects of food supply on moulting growth and spawning of the shrimp Crangon crangon (L.). ICES, C. M. Shellfish Committee, M: 5, 1-7

Möller, P., Rosenberg, R. (1982). Production and abundance of the amphipod Corophium volutator in some marine habitats on the west coast of Sweden. Neth. J. Sea Res. 16: $127-140$

Möller, P., Rosenberg, R. (1983). Recruitment, abundance and production of Mya arenaria and Cardium edule in marine shallow waters, western Sweden. Ophelia 22: 33-55

Muus, B. J. (1967). The fauna of Danish estuaries and lagoons. Distribution and ecology of dominating species in the shallow reaches of the mesohaline zone. Medd. Danm. Fisk. Havunders, N. S. 5 (1): 1-316

Olundh, E., Olsson, 1., Rosenberg, R., Thorell, L. (1975). The By Fjord: ecological investigations on zooplankton, benthic meio- and Inacrofauna and bacteria in the By Fjord. Swedish Environmental Protection Board P. M. 568: $1-94$

Pihl, L., Rosenberg, R. (1982). Production, abundance and biomass of mobile epibenthic marine fauna in shallow waters, western Sweden. J. exp. mar. Biol. Ecol. 57: 273-301

Plagmann, J. von (1939). Enährungsbiologie der Gamele (Crangon vulgaris Fabr.). Helgoländer wiss. Meeresunters. 2: 113-162

Reise, K. (1977). Predator exclusion experiments in an intertidal mud flat. Helgoländer wiss. Meeresunters. 30: 263-271

Reise, K. (1978). Experiments on epibenthic predation in the Wadden Sea. Helgoländer wiss. Meeresunters. 31: 55-101

Stripp, K. (1969). Jahreszeitliche Fluktuationen von Makrofauna und Microfauna in der Helgoländer Bucht. Veröff. Inst. Meeresforsch. Bremerh. 12: 65-94

Wilcox, J. R., Jeffries, H. P. (1974). Feeding habits of the sand shrimp Crangon septemspinosa. Biol. Bull. mar. biol. Lab., Woods Hole 146: 424-434 